\title{
Detection and identification of Chlamydophila psittaci in asymptomatic parrots in Poland
}

\author{
Tomasz Piasecki ${ }^{*}$ Klaudia Chrząstek and Alina Wieliczko
}

\begin{abstract}
Background: Psittacosis, an avian disease caused by Chlamydophila psittaci, can manifest as an acute, protracted, or chronic illness, but can also be asymptomatic. C. psittaci can persist in the host for months to years, often without causing obvious illness, and therefore poses a threat for zoonotic outbreak. We investigated the prevalence of C. psittaci from 156 tracheal swab samples from 34 different species of parrots in Poland, and determined the genotype of strains from the positive samples.

Results: An overall prevalence of $10.3 \%$ was observed using two different PCR assays, both providing similar results. Thirteen of the PCR-positive samples were genotype A, two were genotype B, and one could not be classified.

Conclusions: These results indicate widespread dissemination of C. psittaci in Polish psittacine populations, without any clinical signs of chlamydiosis, and hence could pose a zoonotic hazard. PCR screening provided a definitive diagnosis of psittacosis, and subsequent ompA gene analysis could be helpful for better understanding the epidemiology of the C. psittaci genotypes. To the best of our knowledge, this is the first report of the incidence of C. psittaci in parrots in Poland.
\end{abstract}

Keywords: Chlamydophila psittaci, Psittacine birds, RFLP-PCR

\section{Background}

The order Chlamydiales contains at least four distinct family groups: Chlamydiaceae, Simkaniaceae, Waddliaceae and Parachlamydiaceae. Within the family Chlamydiaceae there are two distinct genera: Chlamydia and Chlamydophila. The Chlamydophila genus has seven recognised species, namely Chlamydophila pecorum, Chlamydophila pneumoniae, Chlamydophila psittaci, Chlamydophila abortus, Chlamydophila caviae (formerly Chlamydophila psittaci guinea pig conjunctivitis strain) and Chlamydophila felis $[1,2]$.

A unique developmental cycle distinguishes Chlamydophila from other intracellular bacteria [3]. The infectious elementary body $(\mathrm{EB})$ and the vegetative reticulate body (RB) are two major developmental forms involved in the cycle. One of the predominant proteins found on the surface of both the EB and $\mathrm{RB}$ forms is the major outer membrane protein (MOMP, OmpA). MOMP makes up $60 \%$ of the total outer membrane protein [4],

\footnotetext{
* Correspondence: tomasz.piasecki@up.wroc.pl

Department of Epizootiology and Clinic of Bird and Exotic Animals, Faculty of Veterinary Medicine, Wrocław University of Environmental and Life Sciences, pl. Grunwadzki 45, Wrocław 50-366, Poland
}

and published data have indicated that it is critical for chlamydial infection [5-7].

C. psittaci has been isolated and described from various birds and mammals [8-10], and has variously been subdivided into the strains/serovars/genotypes A-F, M56 and WC (referred to hereafter as genotypes). Each genotype is assumed to exhibit stringent host specificity: A in psittacine birds, $\mathrm{B}$ in pigeons, $\mathrm{C}$ in ducks and geese, $\mathrm{D}$ in turkeys, $\mathrm{E}$ in pigeons, ducks and others avian species, $\mathrm{F}$ in parakeets, WC in cattle and M56 in rodents [11-14]. All of the C. psittaci genotypes pose a zoonotic threat and are thus of concern to human health. Psittacosis, an infection caused by C. psittaci in birds, can cause acute, protracted, chronic, or subclinical disease, and can persist in the host for months to years, often without causing obvious illness. In humans, the symptoms are mainly non-specific and influenza-like, however, severe pneumonia, endocarditis, and encephalitis are not uncommon [15,16]. Smith et al. [17] reported that there were a total of 935 human cases of ornithosis confirmed by the US Centers for Disease Control and Prevention (CDC) from 1988-2003. In addition, from 2005-2009, 66 human cases of ornithosis were reported to the CDC through 
the Nationally Notifiable Diseases Surveillance System (NNDSS). In general, these cases occurred following exposure to infected pet birds, usually cockatiels, parakeets and macaws. Vanrompay et al. [10] investigated zoonotic transmission of $C$. psittaci within Belgian psittacine breeding facilities. C. psittaci DNA was detected in 59 of 308 (19.2\%) parrots tested, and in six of $46(13 \%)$ bird owners. Genotypes A or E/B were detected in $14.9 \%$ of humans at these facilities. In Poland, during the reporting period of 2000-2011, only 19 human cases of ornithosis were confirmed by the National Institute of Public Health, however, no cases were diagnosed in the last three years of the reporting period (2009-2011) [18]. Despite this detection in humans, little is known about the status of infection of captive parrots in Poland, which could pose a zoonotic hazard. Therefore, to obtain some baseline data for Poland, the prevalence of C. psittaci in various parrot species that did not exhibit clinical signs of infection was determined using two different polymerase chain reaction (PCR) amplification assays. We also used restriction fragment length polymorphism (RFLP) to determine the genotype of the Chlamydophila positive samples.

\section{Methods}

\section{Sample collection}

In total, 156 tracheal swab samples were collected from 34 different parrot species (Table 1). The parrots ranged in age from 8 months to 3 years old. The samples were collected from 2007-2012 from birds that were housed in private aviaries and zoological shops in Poland, and that were in contact with humans. Some of these parrots were raised in an outdoor coop; however there was no direct contact with wild birds. In some cases, the parrots were housed with pigeons. Clinical investigation and oral histories of the birds provided by the owner did not reveal any indication of diseases, including chlamydiosis. The research was conducted with the consent of the $2^{\text {nd }}$ Local Ethical Committee for Animal Experiments (Wroclaw, Poland) (No. 84/2006).

\section{DNA isolation}

DNA was extracted from pharyngeal swab samples using a Genomic DNA Prep Plus kit (A \& A Biotechnology, Gdynia, Poland) according to the manufacturer's instructions, and the extracted DNA was quantified by spectrophotometry (BioPhotometer, Eppendorf, Poland).

\section{CpsiA/B PCR assay}

PCR amplification of the pmp gene was performed using the primers CpsiA, 5'-ATG AAA CAT CCA GTC TAC TGG-3', and CpsiB, 5'-TTG TGT AGT AAT ATT ATC AAA $-3^{\prime}$ [19], and the following cycling conditions: initial
Table 1 The incidence of Chlamydophila psittaci infections in various psittacine species from Poland

\begin{tabular}{|c|c|c|c|}
\hline Genus & Species & $\begin{array}{l}\text { Number of } \\
\text { birds tested }\end{array}$ & $\begin{array}{l}\text { Number of } \\
\text { Ch. psittaci } \\
\text { positive birds }\end{array}$ \\
\hline \multirow[t]{2}{*}{ Agapornis } & Agapornis roseicollis & 2 & 0 \\
\hline & Agapornis personata & 6 & 1 \\
\hline \multirow[t]{4}{*}{ Amazona } & Amazona aestiva & 6 & 1 \\
\hline & Amazona barbadensis & 2 & 0 \\
\hline & Amazona finschi & 4 & 2 \\
\hline & Amazona leucocephala & 2 & 0 \\
\hline \multirow[t]{5}{*}{ Ara } & Ara ararauna & 12 & 0 \\
\hline & Ara chloroptera & 4 & 0 \\
\hline & Ara severa & 1 & 0 \\
\hline & Aratinga jandaya & 3 & 0 \\
\hline & Aratinga solstitialis & 2 & 1 \\
\hline \multirow[t]{2}{*}{ Cacatua } & Cacatua alba & 2 & 0 \\
\hline & Cacatua moluccensis & 1 & 0 \\
\hline Diopsittaca & Diopsittaca nobilis & 1 & 0 \\
\hline Eclectus & Eclectus roratus & 8 & 1 \\
\hline Forpus & Forpus paserinus & 1 & 0 \\
\hline Melopsittacus & Melopsittacus undulatus & 19 & 2 \\
\hline Myiopsitta & Myiopsitta luchsi & 1 & 0 \\
\hline Neophema & Neophema splendida & 1 & 0 \\
\hline Nymphicus & Nymphicus hollandicus & 5 & 0 \\
\hline \multirow[t]{3}{*}{ Platycercus } & Platycercus elegant & 8 & 4 \\
\hline & Platycercus eximius & 3 & 0 \\
\hline & Platycercus icterotis & 1 & 1 \\
\hline \multirow[t]{2}{*}{ Poicephalus } & Poicephalus robustus & 1 & 0 \\
\hline & Poicephalus senegalus & 1 & 0 \\
\hline \multirow[t]{2}{*}{ Polytelis } & Polytelis alexandre & 1 & 0 \\
\hline & Polytelis anthopeplus & 1 & 0 \\
\hline Probosciger & Probosciger aterrimus & 1 & 0 \\
\hline Psephotus & Psephotus haematonotus & 1 & 1 \\
\hline \multirow[t]{3}{*}{ Psittacula } & Psittacula alexandri & 2 & 0 \\
\hline & Psittacula eupatria & 5 & 1 \\
\hline & Psittacula krameri & 30 & 1 \\
\hline Psittacus & Psittacus erithacus & 16 & 0 \\
\hline Trichoglossus & Trichoglossus haematodus & 2 & 0 \\
\hline \multicolumn{2}{|c|}{ Total number (\%) } & 156 & $16(10,26)$ \\
\hline
\end{tabular}

denaturation at $94^{\circ} \mathrm{C}$ for $2 \mathrm{~min}$, followed by 30 cycles of $94^{\circ} \mathrm{C}$ for $30 \mathrm{~s}, 50^{\circ} \mathrm{C}$ for $30 \mathrm{~s}$ and $65^{\circ} \mathrm{C}$ for $2 \mathrm{~min}$, and a final extension at $65^{\circ} \mathrm{C}$ for $10 \mathrm{~min}$. The PCR reaction contained $50 \mathrm{ng}$ of template DNA, 1 U Green Taq polymerase (Fermentas, Vilnius, Lithuania), 10× PCR buffer (Fermentas), $3 \mathrm{mM} \mathrm{MgCl} 2,200 \mu \mathrm{M}$ dNTPs (Fermentas, Vilnius, Lithuania) and $20 \mathrm{pmol}$ of each primer (Genomed, 
Warszawa, Poland). The expected product size amplified by these primers was 2300 bp [20].

\section{MOMP gene PCR assay}

DNA was extracted as described above and then amplified by PCR using the primers CTU, $5^{\prime}$-ATG AAA AAA CTC TTG AAA TCG G-3', and CTL, 5'-CAA GAT TTT CTA GAY TTC ATY TTG TT-3' [21], which target an $\sim 1.1-\mathrm{kb}$ fragment of the highly conserved region of the outer membrane protein A gene, $\operatorname{omp} A$, the structural gene for MOMP [22]. PCR reactions contained 50 ng template DNA, $1 \mathrm{U}$ Green Taq polymerase, 10× PCR buffer, $1.5 \mathrm{mM} \mathrm{MgCl}_{2}, 200 \mu \mathrm{M}$ dNTPs and $20 \mathrm{pmol}$ of each primer in a final volume of $25 \mu \mathrm{l}$. Reaction conditions were as follows: 30 cycles of $1 \mathrm{~min}$ at $95^{\circ} \mathrm{C}, 1 \mathrm{~min}$ at $51^{\circ} \mathrm{C}$ and $2 \mathrm{~min}$ at $72^{\circ} \mathrm{C}$, followed by a final extension at $72^{\circ} \mathrm{C}$ for $7 \mathrm{~min}$.

The amplification products were resolved on a $1.5 \%$ agarose gel, stained with ethidium bromide and visualised using a Gel-Doc UV transilluminator system (BioRad, Warszawa, Poland) and Quantity-One software (BioRad).

\section{PCR-RFLP genotyping}

Samples that were positive for $C$. psittaci were then examined by restriction enzyme digestion. ompA PCR products from the positive samples were digested with 2 $\mathrm{U}$ of $A l u \mathrm{I}$ for $5 \mathrm{~h}$ at $37^{\circ} \mathrm{C}$ to determine their ompA genotype. The restriction products were examined by electrophoresis using a 6\% agarose gel (Resolva, GQT, PRONA, ABO, Gdańsk, Poland) stained with ethidium bromide. Gels were viewed under UV illumination and analysed using Quantity-One software. Following agarose gel electrophoresis, cleavage patterns were compared with the sizes and patterns of the DNA bands from of each of the previously described C. psittaci genotypes, as described by Sayada et al. [23]. Additionally, RFLP-PCR profiles were analyzed by composing a data matrix built on the presence (1) or absence (0) of any fragment appearing in each strain. Cluster analysis of the pairwise similarity values was performed using the UPGMA (unweighted pair group method using averages) algorithm [24] and Dice similarity coefficients.

\section{Results}

Sixteen of 156 the birds tested were positive for C. psittaci using the PCR MOMP gene assay, corresponding to $10.3 \%$ of the examined population (Table 1). The CpsiA/B PCR assay showed 15 positive samples (Table 2), all of which corresponded to positive samples from the MOMP assay. RFLP analysis of the sixteen ompA amplicons revealed that most of the samples displayed a genotype-A pattern (13 samples), with only two samples showing a genotype-B pattern (Figure 1). We were unable to assign a genotype to one sample because it did not match any of the previously
Table 2 The list of Ch.psittaci-possitive parrots

\begin{tabular}{|c|c|c|c|c|}
\hline \multirow[t]{2}{*}{ Species } & \multirow{2}{*}{$\begin{array}{c}\text { Laboratory } \\
\text { No. }\end{array}$} & \multicolumn{2}{|c|}{ PCR } & \multirow{2}{*}{$\begin{array}{l}\text { RFLP-PCR } \\
\text { Genotype }\end{array}$} \\
\hline & & $\begin{array}{c}\text { OMP gene } \\
\text { assay }\end{array}$ & CpsiA/B & \\
\hline Agapornis personata & 987 & + & + & A \\
\hline Amazona aestiva & 1235 & + & + & A \\
\hline Amazona finschi & 542 & + & - & NN \\
\hline Amazona finschi & 541 & + & + & A \\
\hline Aratinga solstitialis & 1214 & + & + & A \\
\hline Eclectus roratus* & 624 & + & + & $\mathrm{B}$ \\
\hline Melopsittacus undulatus* & 1240 & + & + & $\mathrm{B}$ \\
\hline Melopsittacus undulatus & 1306 & + & + & A \\
\hline Platycercus elegans & 902 & + & + & A \\
\hline Platycercus elegans & 903 & + & + & A \\
\hline Platycercus elegans & 1229 & + & + & A \\
\hline Platycercus elegans & 1023 & + & + & A \\
\hline Platycercus icterotis & 1026 & + & + & A \\
\hline Psephotus haematonotus & 831 & + & + & A \\
\hline Psittacula eupatria & 1028 & + & + & A \\
\hline Psittacula krameri & 1220 & + & + & A \\
\hline
\end{tabular}

The results of genotyping. Legend: *the birds which were kept with pigeons, NN-unidentified.

published patterns. Interestingly, no product was amplified from this sample in the CpsiA/B PCR assay.

Dendrogram of OMP- RFLP patterns of AluI digests was shown on Figure 2. A cluster analysis grouped all 16 strains into one cluster (A), which was divided into two smaller clusters (A1 and A2) with a 78\% similarity coefficient. The two samples showing a genotype-B pattern belonged to the A1 cluster and showed $88 \%$ similarity in their restriction profiles. The remaining strains, all with a genotype-A pattern, belonged to the second, smaller cluster (A2), and had a high level of similarity. The remaining untypeable strain showed $82 \%$ similarity to the genotype-A pattern in its restriction profile.

\section{Discussion}

C. psittaci is generally an avian pathogen, however it can cause zoonotic disease in humans (ornithosis). Birds can shed this bacterium into the environment both when overtly ill, and when asymptomatic. The purpose of this investigation was to survey and collect baseline data, for the first time in Poland, on the prevalence of C. psittaci in parrots, and to determine the genotypes of any positive isolates. All birds examined in this investigation were clinically healthy at the time of sampling; however it is possible that the birds had asymptomatic infections. Asymptomatic animals pose a threat to individuals working with these birds in various facilities and capacities.

We determined a prevalence of C. psittaci of $10.3 \%$ amongst captive parrots in Poland. According to official 


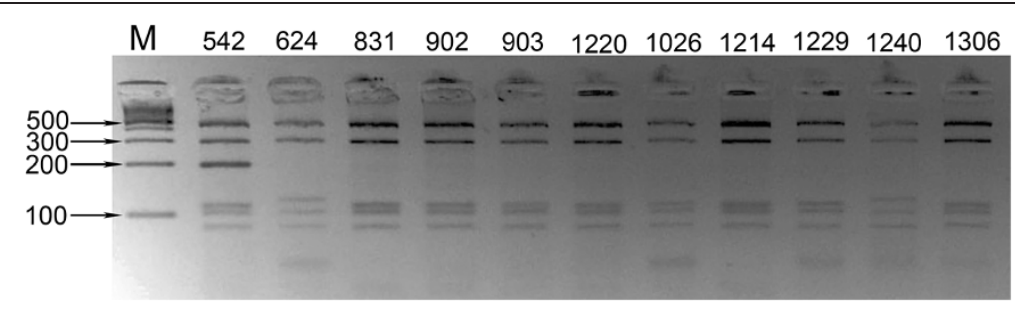

Figure 1 Ch.psittaci RFLP profiles generated folowing RE (restriction endonuclease) digestion of OMP PCR gene products from 11 strains. M-100bp marker, Lane 2 (No. 542)- unclassified genotype pattern, Lane 3 (No. 624) and lane 11 (No. 1240) - genotype-B pattern, residualgenotype-A pattern.

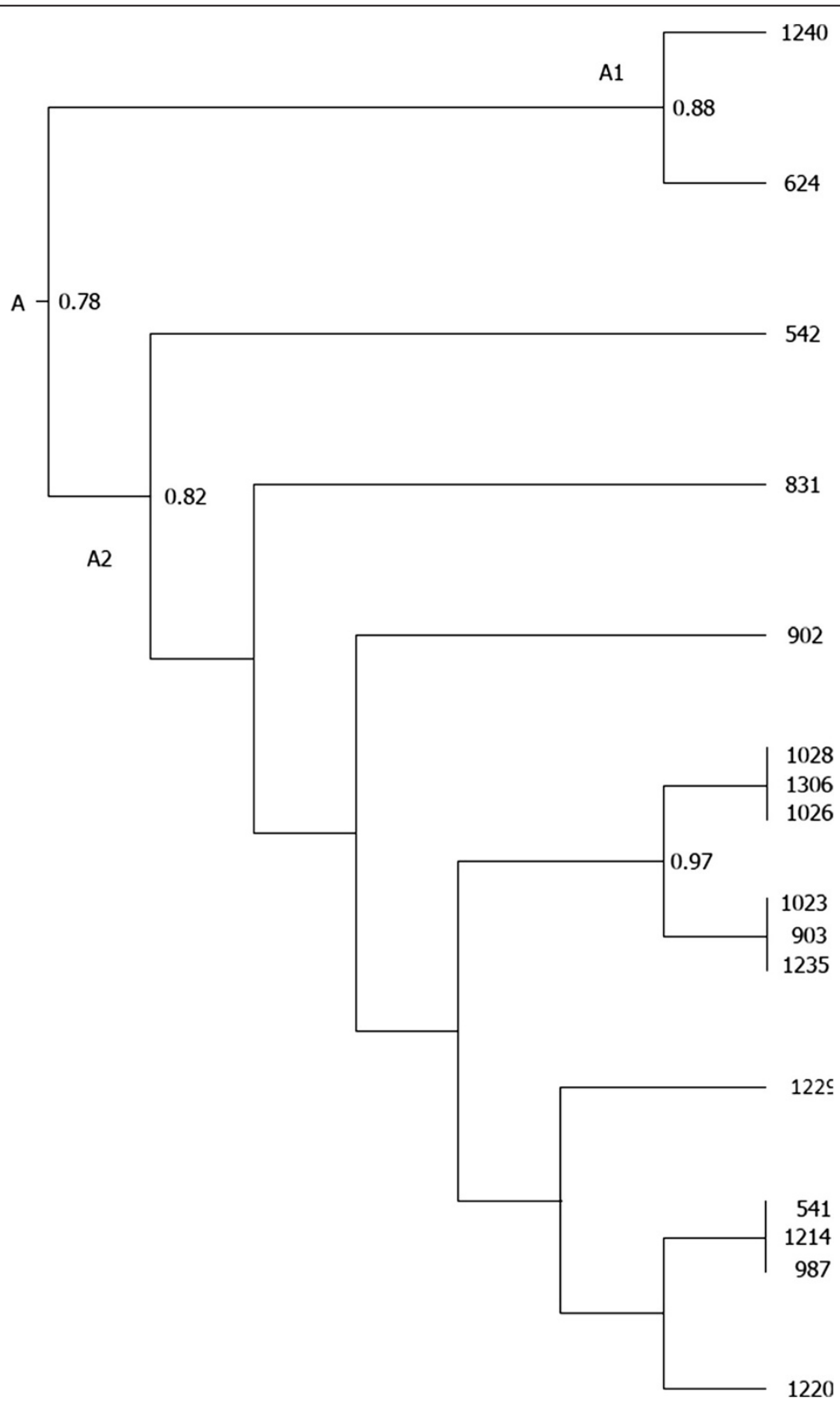

Figure 2 Dendrogram of OMP- RFLP patterns of Alul digests. 
statements, C. psittaci was not reported in humans in Poland between 2009 and 2011. It is possible that many more cases do occur but are not correctly diagnosed or reported. Diagnosis of ornithosis could be hampered by the lack of sensitive detection methods. Culturing-based identification is only performed in select laboratories, and serologic tests do not fully differentiate the various chlamydial microbes.

We noted that C. psittaci genotype-A is the most prevalent amongst parrots in Poland, which is consistent with the global predominance of genotype-A C. psittaci in parrots [14]. Interestingly, C. psittaci genotype-B is commonly found in pigeons $[25,26]$. The two samples showing a genotype-B pattern in the current study were isolated from parrots that had been raised in pigeon-shared aviaries, thereby indicating cross-species transmission, and the susceptibility of parrots to this genotype. The ungenotypeable strain may belong to another member of the Chlamydophila genus, as this sample was not amplified by the CpsiA/B PCR assay, which Larocau et al. [20] showed only amplifies C. abortus, C. psittaci and C. caviae strains.

This study showed that the two PCR-based methods yielded similar results, both with a high degree of sensitivity. However, the advantage of the MOMP PCR assay is the downstream genotyping by RFLP. This is especially important, as each genotype is assumed to exhibit stringent host specificity. Thus, RFLP-ompA genotyping could be a sensitive method for identifying the susceptibility of animals to different genotypes or cross-species transmission. This assay may also be helpful for better understanding the epidemiology of $C$. psittaci genotypes. Nevertheless, Larocau et al. [20] showed that a CpsiA/B RFLP assay distinguished between the different serovars of avian chlamydia strains, other than between serovars $\mathrm{B}$ and $\mathrm{E}$.

\section{Conclusions}

We determined that the prevalence of $C$. psittaci in asymptomatic captive parrots in Poland was $10.3 \%$. However, no ornithosis was reported in humans during the corresponding sampling period. Nonetheless, there may have been unreported or misdiagnosed cases amongst people in contact with these birds. We determined that the PCR-based typing techniques were rapid and sensitive for identifying $C$. psittaci genotypes in the majority of cases, particularly when using subsequent RFLP of the MOMP gene amplification products. Large scale analysis of parrots and their handlers using the ompA PCR-based assays could shed light on the incidence of chlamydiosis and ornithosis, and the epidemiology of C. psittaci in Poland.

\section{Competing interest}

The authors declare that we have no competing interest.

\section{Authors' contributions}

TP conceived and designed the study, performed laboratory assays and revised the manuscript. KC participated in design the study, laboratory assays, drafted and revised the manuscript. AW participated in coordination the study and helped to draft the manuscript. All authors read and approved the final manuscript.

Received: 9 August 2012 Accepted: 27 November 2012

Published: 4 December 2012

\section{References}

1. Everett KDE, Bush RM, Anderson AA: Emended description of the order Chlamydiales, proposal of Parachlamydiaceae fam. Nov. and Simkaniaceae fam. nov., each containing one monotypic genus, revised taxonomy of the family Chlamydiaceae, including a new genus and five new species, and standards for identification of organisms. Int J Syst Bacteriol 1999, 49:425-440.

2. Garity GM: In Bergey's Manual of Systematic Bacteriology, Volume 1. 2nd edition. Edited by Boone DR, Castenholz RW. USA: Springer-Verlag; 2001.

3. Moulder JW, Hatch TP, Kuo CC, Schachter J, Storz J: Order II: Chlamydiales. In Bergey's manual of systematic bacteriology. 1st edition. Edited by Krieg NR, Holt JG. Baltimore, MD: Williams \& Wilkins; 1984:729-739.

4. Caldwell HD, Kromhout J, Schachter J: Antigenic Analysis of the Major Outer Membrane Protein of Chlamydia spp. Infect Immun 1981, 31:1161-1176.

5. Wyllie S, Ashley RH, Longbottom D, Herring AJ: The major outer membrane protein of Chlamydia psittaci functions as a porin-like ion channel. Infect Immun 1998, 66:5202-5207.

6. Su H, Watkins NG, Zhang YX, Caldwell HD: Chlamydia trachomatis-host cell interactions: role of the chlamydial major outer membrane protein as an adhesin. Infect Immun 1990, 58:1017-1025.

7. Hatch TP: Disulfide cross-linked envelope proteins: the functional equivalent of peptidoglycan in chlamydiae? J Bacteriol 1996, 178:1-5.

8. Hotzel H, Berndt A, Melzer F, Sachse K: Occurrence of Chlamydiaceae spp. in a wild boar (Sus scrofa L.) population in Thuringia (Germany). Vet Microbiol 2004, 103:121-126.

9. Szeredi L, Hotzel H, Sachse K: High prevalence of chlamydial (Chlamydophila psittaci) infection in fetal membranes of aborted equine fetuses. Vet Res Commun 2005, 29:37-49.

10. Vanrompay D, Harkinezhad T, van de Walle M, Beeckman D, van Droogenbroeck C, Verminnen K, Leten R, Martel A, Cauwerts K: Chlamydophila psittaci Transmission from Pet Birds to Humans. Emerg Infect Dis 2007, 13:1108-1110.

11. Andersen AA: Serotyping of Chlamydia psittaci isolates using serovarspecific monoclonal antibodies with the microimmunofluorescence test. J Clin Microbiol 1991, 29:707-711.

12. Andersen AA: Two new serovars of Chlamydia psittaci from North American birds. J Vet Diagn Invest 1997, 9:159-164.

13. Geens T, Desplanques A, van Loock M, Bönner BM, Kaleta EF, Magnino S, Andersen AA, Everett KD, Vanrompay D: Sequencing of the Chlamydophila psittaci ompA gene reveals a new genotype, $E / B$, and the need for a rapid discriminatory genotyping method. J Clin Microbiol 2005, 43:2456-2461.

14. Vanrompay D, Andersen AA, Ducatelle R, Haesebrouck F: Serotyping of European isolates of Chlamydia psittaci from poultry and other birds. J Clin Microbiol 1993, 31:134-137.

15. Johnson-Delaney C: Potential zoonoses from nontraditional pets with particular attention to the immunocompromised pet owner. J Sm Exotic Anim Med 1993, 2:103-111.

16. Salisch H, Malottki KV, Ryll M, Hinz KH: Chlamydial infections of poultry and human health. Worlds Poultry Sci J 1996, 52:279-308.

17. Smith KA, Bradley KK, Stobierski MG, Tengelsen LA: Compendium of measures to control Chlamydophila psittaci (formerly Chlamydia psittaci) infection among humans (psittacosis) and pet birds. J Am Vet Med Assoc 2005, 226:532-539.

18. National Institute of Public Health: Epidemiological reports. http://www.pzh. gov.pl/oldpage/epimeld/index_a.html.

19. Longbottom D, Russell M, Dunbar S, Jones G, Herring A: Molecular cloning and characterization of the genes coding for the highly immunogenic cluster of $90 \mathrm{kDa}$ envelope proteins from the Chlamydia psittaci subtype that causes abortion in sheep. Infect Imunol 1998, 66:1317-1324.

20. Laroucau K, Souriau A, Rodolakis A: Improved sensitivity of PCR for Chlamydophila using pmp genes. Vet Microbiol 2001, 82:155-164. 
21. Denamur J, Sayada C, Souriau A, Orfila J, Rodolakis A, Elion J: Restriction pattern of the major outer-membrane protein gene provides evidence for a homogeneous invasive group among ruminant isolates of Chlamydia psittaci. J Gen Microbiol 1991, 137:2525-2530.

22. Vanrompay D, Butaye P, Sayada C, Ducatelle R, Haesebrouck F: Characterization of avian Chlamydia psittaci strains using omp 1 restriction mapping and serovar-specific monoclonal antibodies. Res Microbiol 1997, 148:327-333.

23. Sayada $\mathrm{CH}$, Andersen AA, Storey CH, Milon A, Eb F, Hashimoto N, Hirai N Elion J, Denamur E: Usefulness of omp1 restriction mapping for avian Chlamydia psittaci isolate differentiation. Res Microbiol 1995, 146:155-165.

24. Li WH: Simple method for constructing phylogenetic trees from distance matrices. Proc Natl Acad Sci U S A 1981, 78:1085-1089.

25. Heddema ER, Ter Sluis S, Buys JA, Vandenbroucke-Grauls CM, van Wijnen JH, Visser CE: Prevalence of Chlamydophila psittaci in fecal droppings from feral pigeons in Amsterdam, The Netherlands. Appl Environ Microbiol 2006, 72:4423-4425.

26. Sachse K, Kuehlewind S, Ruettger A, Schubert E, Rohde G: More than classical Chlamydia psittaci in urban pigeons. Vet Microbiol 2012, 157:476-480.

doi:10.1186/1746-6148-8-233

Cite this article as: Piasecki et al:: Detection and identification of Chlamydophila psittaci in asymptomatic parrots in Poland. BMC Veterinary Research 2012 8:233.

\section{Submit your next manuscript to BioMed Central and take full advantage of:}

- Convenient online submission

- Thorough peer review

- No space constraints or color figure charges

- Immediate publication on acceptance

- Inclusion in PubMed, CAS, Scopus and Google Scholar

- Research which is freely available for redistribution 